\title{
1 \\ FROM SILENT SPRING TO THE THREAT OF A FOUR-DEGREE WORLD
}

\section{The Context of Tony McMichael's Career}

\author{
COLIN D. BUTLER AND ALISTAIR WOODWARD
}

\section{Abstract}

This chapter positions the late Tony McMichael's contributions in the social, political and ecological context in which he worked from the early 1970s to the present. We document how his research and writing were shaped by this milieu and explore some of the barriers, challenges and opportunities that shaped his career.

McMichael's work was distinguished in two respects. These are, first, the range of epidemiology subspecialties that he mastered (including occupational health, cancer, nutrition and environmental health), and second, the depth and lasting impact of his research. We provide examples of the work he and his colleagues carried out on lead, smoking, health inequalities and the links between diet and cancer. In recent decades, Tony was probably known best for his focus on the effects of adverse global ecological and environmental changes, and climate change in particular. He contributed to an improved understanding of causality within epidemiology, rejecting an exclusive focus on downstream, 'proximal' determinants of health and disease. He also challenged his discipline to extend its temporal boundaries, both into the past and the future.

There are many challenges ahead for epidemiology and for the broader discipline it endeavours to serve, public health. Tony McMichael's thinking and writing, and the example he set as an epidemiologist advocate for environment and health, will be as relevant and influential in the future as they have been in the past four decades. 


\section{Introduction}

Two of the greatest 19th-century French health scientists were Claude Bernard and Louis Pasteur. At the end of his life, Pasteur was said to have conceded 'Bernard was right - the microbe is nothing: the milieu is everything' (James, 1982-84; Goldstein, 2008). Clearly, the milieu is not everything - but it certainly matters, for people as well as for microbes. In this chapter, we outline the major political and social events of the past 40 years and consider their influence on Tony McMichael's remarkable career.

\section{‘It's Time’ - The 1970s}

In 1972, smoking in Australian society seemed ubiquitous, and the lighted cigarette was prevalent in restaurants, theatres, public transport, university tutorials and hospitals. Blood lead concentrations of $20 \mu \mathrm{g} / \mathrm{l}$ were unremarkable. Abortion was illegal, abductions of mixed race children by Australian welfare agencies had just ended and the deceptive removal of newborn infants from some unmarried white women for adoption by childless white couples was still practised. The pill, first trialled without informed consent on poor women in Puerto Rico in the mid-1950s (Duster, 2006), was just beginning to alter Australian demography.

Epidemiology was an unusual career choice for medical graduates when Tony, 1967 President of the National Union of Australian University Students, became the first PhD student at the newly established Department of Social and Preventive Medicine at Monash University, in Melbourne. Tony was supervised by the Foundation Professor, Basil Hetzel (see Chapter 2, this volume), with whom Tony published papers on mental health (McMichael and Hetzel, 1974, 1975) and a book, The LS Factor (Hetzel and McMichael, 1987) (see Reprint F, Part 4, this volume).

In the early 1970s, the Vietnam War dragged on in the face of vociferous public opposition, inflamed by the conscription of men too young to vote but old enough to fight. Opposition to the war forged networks in civil society, including among student groups and labour unions. These same actors, with Indigenous organisations, were also involved in Aboriginal land rights movements and related civil rights activism. The Aboriginal Tent Embassy was established in Canberra; the Women's Electoral Lobby was created to ensure that women's rights were on the political agenda; and in 1972, Gough Whitlam was elected to government on a mandate for change (his campaign slogan was 'It's time'). 
Non-violent protests continued against the building of the three dams that drowned Lake Pedder, Tasmania; these led to the founding of the world's first ecological political party, also in 1972.

Vegetarianism was becoming fashionable; Diet for a Small Planet (Lappé and Collins, 1971) sold in large numbers. It was the heyday of The Club of Rome: one of its reports, The Limits to Growth (Meadows et al., 1972), sold millions of copies. The 1972 Stockholm Conference on Environment and Development ('Rio minus twenty') was championed by the microbiologist turned planetary ecologist, René Dubos (1980; Piel and Segerberg Jr, 1990) and two years later, Karim Singh, representing Indian Prime Minister, Indira Gandhi, at the 1974 Bucharest meeting on population, famously declared that 'development is the best contraceptive' (Sinding, 2000). Demographic and development issues were to become an enduring theme in McMichael's work (see Chapters 9, 10, 14, 17, 22, this volume; and McMichael, 1995).

The publisher, Richard Walsh, spotted Tony's writing gifts, and for a while his Spaceship Earth columns were a regular feature in Nation Review (see Box 1.1). Reading these columns today brings to mind Tony's prescience. He wrote about issues such as global pollution, resource scarcity and human population pressure, which are familiar today (Ehrlich and Ehrlich, 2013) but which scarcely registered on the agenda of public health in the 1970s. There were rare exceptions, such as a paper in the Medical Journal of Australia by the ecologist, Stephen Boyden (1972), who later became a close colleague of Tony's (Foreword, this volume). The orthodox scientific literature then included no outlets such as Ecosystem Health or Global Change and Human Health (both of which McMichael was an editor). While neither journal still exists, their legacy continues in EcoHealth. 


\section{Box 1.1 This is bigger than the sanitary movement TONY MCMICHAEL}

CYNICS have said that the ecology movement is just a passing bandwagon; an artificial and ephemeral conscience-salving exercise for idle middle class minds. Well, middle class minds (among all radical Review readers there must be a few middle class minds) if the cap fits ...

However, a recently published Gallup poll reports that 62 percent of Australians think that the world will be unliveable in twenty years without prompt curbs on population and pollution. You can't tell me that ecology bandwagoning has become a widespread indulgence of the silent majority. Rather, it suggests that the current upsurge of concern reflects genuine doubt about the world's future if today's trends continue.

Indeed, the prevailing mood has a clear precedent in the sanitary movement of the nineteenth century. The preceding burst of affluence; the subsequent quickening of social conscience towards deprived minorities (industrial slum dwellers then - racial minorities, women, and homosexuals now); the broad social and political base of dismay over a deteriorating quality of life; and the recognition that the laisser-faire ethic is inadequate (economic theory then industrial technology now). These are the common themes in the environmental revolutions of then and now.

The English suddenly realised 130 years ago that, in the words of one historian, they were "living on a dungheap". The early years of the industrial revolution had spawned a new and comfortable middle class, and had extruded overcrowded industrial slums where poverty and disease were rife.

In the first flush of steam powered laisser-faire economics, the bourgeoisie dreamed of progress unlimited. Government was best that governed least. There were lots of unprecedented treasure at the end of the industrial rainbow. Outside these middle class dreams, the newly migrated urban working class festered in fetid slums, their fevered infants dying of infection, their children working in pits, their adults exposed to disease and industrial injury.

Then the rainbow tarnished. Social reality intruded into men's consciousness. Middle class optimism was tempered with awareness of the accumulating squalor amongst the working class. A few consciences were pricked, and, in the 1840s, social reform movements gathered momentum.

Equally important in the rude awakening, however, was the realisation that the shoddiness of the slums was impinging on the general quality of urban life. Infectious disease spilled over the whole community - cholera, typhoid and "consumption" (tuberculosis). Water supplies became contaminated, rivers turned foul, the air turned black, and (because of the high sulphur content of British coal) the acidic air started eating holes in domestic middle class masonry.

* $\quad$ Spaceship Earth. THE REVIEW, April 8-14, 1972, 708. 
People were perturbed. Their future was turning sour. They expected remedial action by the government - but the government, accustomed to being seen but not heard during the first flowering of laisser-faire capitalism, was slow to act against the mounting urban squalor. People became disenchanted. A mood of dismay and dissent stirred the nation, forging strange alliances between church and industrialist, Whig and Tory, worker and gentleman.

In this emerging field of public health, sir Edwin Chadwick, a Benthamite utilitarian, propounded the empirical connection between disease and urban squalor. Traditional mystical interpretations of disease (especially infectious disease) were replaced by an empiricist working theory: "All smell is disease." And so, even though the germ theory of infectious disease had not yet been discovered, the sanitary movement was launched.

Ultimately, as public health polemic became self-evident truth, the fundamental importance of sanitation became enshrined in the culture. Notwithstanding the fact that they only bath once a week, it is fair to say that, for the last hundred years, the British have regarded soap, sewers and sanitation as prerequisites for civilisation.

Now, in the 1970s, our society is confronted by another environmental threat to health and welfare. Postwar affluence is being tempered with the realisation that unrestrained modern technology is unleashing new agents of biological damage - radioactive wastes, noxious fumes, persistent pesticides, heavy metal contaminants, and so on.

Technological wastes and side effects are the modern equivalent of last century's urban excreta. The effects on health may be less dramatic - but they are no less real. Chronic respiratory disease is now on the increase in the cities of the developed world (after allowing for the effects of cigarette smoking). Likewise, premature deafness, and the road toll. Similar fears exist for the effects of mercury lead and cadmium on brain function, pesticide residues on liver and brain function, and carbon monoxide on heart disease.

As in the 1840s, it is being realised (in America, if not here) that certain deprived groups are the most exposed to some sorts of pollution. Lead poisoning is prominent among ghetto children, chronic respiratory disease is prominent in working class suburbs beneath the shadow of industrial smoke-shacks. Consciences are again being pricked.

They are becoming the immediate spurs to action - concern over human physical health and welfare. Related, but less immediate concerns are with the soul-destroying competitive anonymity of life in megalopolis, and the destruction of esthetic and recreational assets.

The sanitary movement changed the world because it changed men's understanding of disease. In today's era of recent affluence and current social uneasiness and dissent, the ecology movement may yet change the world for the better. But the changes required are more fundamental and urgent than those of last century. 
Twenty-one years after McMichael's doctoral graduation, the development of niche journals on global environmental change and health was foreshadowed by keynote addresses delivered at the 1993 congress of the International Epidemiological Association, held in Sydney, by two University of Adelaide medical graduates. One was Tony McMichael (1993a), the other John Last (1994), editor of the Dictionary of Epidemiology. Both addresses led to papers in the International Journal of Epidemiology (Last, 1994; McMichael, 1993a).

In the same year, and of even greater significance, McMichael (1993b) published Planetary Overload (see Reprint A, Part 1, this volume). Never before had an epidemiologist written in depth about the questions that had been raised so strongly by leading ecologists in earlier decades (Carson, 1962; Ehrlich, 1968; Shepard and McKinley, 1969). For example, the miracle of the Green Revolution brought relief from abysmal hunger from the 1960s (Tribe, 1994), but Tony and others pointed out that there were still serious obstacles in the way of sustainable production and equitable distribution of global food supplies (see Chapter 14, this volume). McMichael's influential book linked the concerns of ecologists and environmental scientists to the health of the human population, worldwide.

\section{Environmental Contaminants, Ecology and Health}

The public debate on the effects of chemical contamination and exogenous hormones on human and animal health, and the environment more broadly, had been launched in 1962 by Rachel Carson's book, Silent Spring (Carson, 1962). These recurred as a theme throughout Tony's career (McMichael and Potter, 1980; Potter and McMichael, 1983), especially in the time he was involved with the Commonwealth Scientific and Industrial Research Organisation (CSIRO) (1976-83), the International Agency for Research on Cancer (IARC) (Chair of the Scientific Committee, 1989-92) and the International Society for Environmental Epidemiology (ISEE), where he was president from 2008 to 2009. Many chapters in this volume $(3,5-8,11-14,18,20,21,24,33$ and 34) by colleagues from these organisations $^{1}$ are included in this book; one (Chapter 11) focuses on overlapping material - epigenetics. Another influence on Tony's work was Shepard and McKinley's (1969) book, The Subversive Science, Essays Towards an Ecology of Man. The use of the word 'subversive' dates to a short but influential paper from 1964, which argued that ecology might be 'taken seriously as an instrument for the long-run welfare of mankind' (Sears, 1964). Subversive Science included chapters by René Dubos, Lynn White, Alan Watts and Aldo Leopold.

1 Not necessarily contemporaneous. 


\section{Diet and Cancer}

When one of the authors of this chapter started medical school in 1980, he was told that diet had virtually nothing to do with health, quite contrary to the position often taken even then by journalists, countercultural activists, members of new religions and complementary and alternative medical practitioners. Much of what was known at that time about diet and health was not in quantitative form and could not be judged against the famous Bradford Hill (1965) criteria to assess causality. In the 1980s, McMichael and his colleagues at the CSIRO Division of Human Nutrition published extensively on the links between nutrition and cancer (and other conditions), but more importantly, they demonstrated the general principle: diet indeed matters to health. McMichael was a member of the international panel that produced Food, Nutrition, and the Prevention of Cancer: A Global Perspective, a seminal 1997 report on the feasibility of reducing cancer incidence through diet and other environmental factors (World Cancer Research Fund Panel (Potter J.D. Chair), 1997). Several chapters of this volume (11, 13-16) concern diet, health and nutrition.

\section{Lead}

McMichael and colleagues are well-known for a large cohort study of child development carried out at Port Pirie, South Australia, the site of what is still the world's third largest lead-zinc smelter. The study showed that levels of lead once thought to be quite acceptable had caused neurological harm, including impaired cognitive development (see Chapter 7 in this book and Reprint D in Part 3). These findings had an important impact on policies, including the withdrawal of lead from petrol.

In 1970, in the USA, an occupational exposure to lead that resulted in a concentration of 70-80 $\mu \mathrm{g} / \mathrm{dl}$ was considered acceptable (Ambrose et al., 2000). Today, there is good evidence that lead levels as low as $2.4 \mu \mathrm{g} / \mathrm{l}$ are associated with loss of IQ points (Lanphear et al., 2005), but contamination of the environment by lead continues. Despite considerable effort, lead levels in children in Port Pirie remain elevated, with about 25 per cent of children aged five having levels above $10 \mu \mathrm{g} / \mathrm{dl}$, due to the persistence of lead-carrying dust from the smelter (Taylor et al., 2013). Tony's best-known contribution to occupational health on 'the healthy worker effect' is reprinted in Part 2, this volume (see Reprint C), but he made other contributions in this field, including a study of cancer mortality among rubber workers in Brazil (McMichael et al., 1976). Chapters 4-6 in this book relate especially to occupational health. 


\section{Climate Change and Health}

The long-term effects of the accumulation of greenhouse gases were first described in the 19th century, and were the subject of a seminal paper (Callendar, 1957) in the International Geophysical Year, published when McMichael was still at high school. His 'Spaceship Earth' papers did not refer to climate change. However, the topic became more prominent in the late 1980s, an era leading up to the Ottawa Charter for Health Promotion, the Brundtland Report, the Montreal Protocol and, in 1992, the Earth Summit itself - an extravaganza held in Rio de Janeiro that was attended by 103 heads of state. ${ }^{2}$

About this time, papers linking climate change and health appeared in the New England Journal of Medicine (Leaf, 1989), The Lancet (Editorial, 1989) and, soon after, in an editorial written by McMichael in the Medical Journal of Australia (see Reprint G, Part 5, this volume). This was the first such publication by a public health or medical worker in the Australian scientific literature (McMichael, 1991). McMichael then had the vision, persistence, leadership qualities and opportunity to bring together a co-edited book, Climate Change and Human Health, probably the first in the world (authored or edited) on this topic, published by the World Health Organization (WHO) in 1996 (McMichael et al., 1996).

McMichael had noted that the first Intergovernmental Panel on Climate Change (IPCC) assessment (1990) contained no chapter on health and said very little about the subject throughout. This deficit was remedied in the second and third assessments, when McMichael served as coordinating lead author, a task shared by Alistair Woodward and Kirk Smith in the fifth assessment (see Chapters 12 and 34, this volume). Several other IPCC contributors to the health chapter have also written in this book (Chapters 14, 20 and 33). Many other chapters of this volume (including 10, 11, 13-15, 17-24 and 30-38) also discuss climate change.

Today, the field of climate change and human health has expanded enormously, but still policymakers and the general public do not have a full understanding of its significance. Already, temperature anomalies of 20 degrees $\mathrm{C}$ have been reported in the Arctic. ${ }^{3}$ Ice melt is accelerating, not only from Greenland but also from large parts of Antarctica (Shepherd et al., 2012). There are concerns that the polar jet stream has been deformed, delivering blasts of frigid air to mid-latitudes. ${ }^{4}$ Sea level rise from melting land ice is increasing and remains on track with the most pessimistic IPCC projections (Rahmstorf et al., 2012).

2 www.un.org/geninfo/bp/enviro.html, accessed 10 April 2015.

3 arctic-news.blogspot.com.au/2012/12/arctic-anomalies-linked-to-extreme-weather.html, accessed

10 April 2015.

4 arctic-news.blogspot.com.au/2012/12/polar-jet-stream-appears-hugely-deformed.html, accessed 10 April 2015. 
Emissions of carbon dioxide are tracking high-end warming projections and the chance of a 'two-degree world' appears to be fading (Peters et al., 2012). There are reports of greenhouse gas emissions, especially methane, arising from the Arctic, from expanding wetlands, melting tundra and possibly even melting deposits of methane hydrate (Shakhova et al., 2010; Graef et al., 2011). The possibility of positive (amplifying) feedbacks to climate change has been recognised for several decades (Cicerone, 1988), and becomes more serious as the rate of environmental change increases.

Some extreme weather events are more common than in previous decades (Chapter 21), and climate change may be an amplifying factor through, for instance, increased sea surface temperatures and higher sea levels (Trenberth, 2011). Collectively, these changes are eroding the environmental foundations of population health. The climate scientist, Hans Schellnhuber, has warned that the difference between two degrees and four degrees of warming may be civilisation itself. We are playing, he warns, 'Earth roulette' (Schellnhuber, 2010). Several chapters contemplate civilisation decline and how we might transform it so that humanity continues to prosper (Chapters 30 and 37, this volume).

\section{Inequality and Health}

As McMichael's career was warming up, social opportunities for many were starting to narrow, driven by what the economist, Jeffrey Sachs, called libertarianism (Sachs, 2012), an extreme form of what others label neoliberalism, economic rationalism, economism, marketism, and in the USA, Reaganomics, and in New Zealand, Rogernomics. Factors that contributed to this political shift included the cyclic nature of economics and steep rises in the cost of living, brought about by the first significant spike in oil prices (Szreter, 1997). Although the 1972 oil squeeze was typically presented in a negative light, money paid to the Organization of the Petroleum Exporting Countries (OPEC) for its oil was, in fact, helping to redistribute global income. It perhaps improved global social justice by redistributing funds from petrol pumps in the West, not just to sheiks and oil barons but also, in some cases, to the citizens of oil-rich nations.

By the 1980s, as libertarianism strengthened, it was less propitious to speak against other forms of injustice, whether in the West or globally. This decade saw little of the aspiration and idealism of individuals such as Albert Schweitzer, Martin Luther King, Lester Pearson and WHO Director, General Halfdan Mahler, who had endorsed calls for 'Health for All by 2000' (Werner and Sanders, 1997; Butler, 2008). 
In association with this shift to the political right, McMichael suggested that many epidemiologists were retreating from large-scale aspirations, essentially political, to focus on narrower, more 'downstream' positions (McMichael, 1999). (See 'Prisoners of the Proximate: Loosening the Constraints on Epidemiology in an Age of Change'; Reprint B, Part 1, this volume.) In this, he was undoubtedly stimulated by Gary Taubes' paper, 'Epidemiology faces its limits' (Taubes, 1995), an article recommended for students studying 'emerging themes in epidemiology' at the London School of Hygiene and Tropical Medicine (LSH\&TM) in 1996, as one of the authors of this chapter recalls. Taubes argued that the easy questions in epidemiology (e.g. the causes of cholera or lung cancer) had been answered, and that epidemiologists were now spending most of their time in blind alleys searching for increasingly trivial causal cofactors. In response, McMichael argued for a closer investigation of broader 'upstream' determinants, following a path explored by his predecessor at the LSH\&TM, the influential British epidemiologist, Geoffrey Rose. Rose famously had pointed out that causes had causes (Rose, 1992), a point also highlighted in The LS Factor (Part 4, this volume).

One colleague from the LSH\&TM has written a chapter in this book (31); another chapter (22) is by Andy Haines, appointed as Dean soon after Tony had returned to Australia..$^{5}$ Another contribution (Chapter 37) is from Bob Douglas, who recruited Tony as foundation professor of environmental health at the University of Adelaide. Later, Tony succeeded Bob as Director of the National Centre for Epidemiology and Population Health (NCEPH).

\section{The 'Epidemiological Wars' Concerning Poverty and Disease}

In the late 1990s, there was a well-publicised clash of opinions on the nature and scope of epidemiology. This debate was later described (with a touch of hyperbole) as 'the epidemiology wars'. On one side was Ken Rothman, famous and highly esteemed as editor of Modern Epidemiology and the journal, Epidemiology. Despite stating explicitly that 'all poverty is unacceptable', Rothman and his colleagues argued that epidemiologists should not and could not try to alter the fundamental determinants of health, especially poverty and disadvantage:

Is poverty eradication a public health programme? How exactly should it be accomplished? ... Perhaps the critics believe that epidemiologists should second-guess economists and attempt to eradicate poverty using 
their own epidemiological model. Given the scope of the task, sympathy might go to the epidemiologists who prefer to focus on a comparatively simple problem, such as the causes of cancer. (Rothman et al., 1998, p. 812)

But, what is left? Remedies - polypills or magic bullets - that cost-effectively would relieve suffering and extend life? The suggestion that epidemiologists should focus on 'comparatively simple' problems, such as the causes of cancer, suggests aetiological frameworks that exclude social phenomena such as poverty, and is, incidentally, dismissive of Rose's challenge to seek the 'causes of the causes'. For instance, smoking is a cause of cancer, a fact established by epidemiologists. But to change the frequency and harmfulness of smoking, one needs to know of its association with poverty (among other things) (Graham, 1987). Some might say that it is the task of other public health professionals to grapple with questions related to social policy, but others argue that epidemiologists can play an important role; for example, by advising policymakers as to whether poverty is a major or minor causal factor.

McMichael (1998) agreed that eradicating poverty was 'beyond the capacity of epidemiology', but disputed that this task should be left to economists, or any other single discipline or professional group. Others took a similar position, including Woodward and Kawachi (2000), who suggested a variety of reasons for tackling health inequalities. Apart from the matter of justice or fairness, there are frequently 'spillover effects' (such as poverty-related infectious diseases and violence) that should motivate the better off. In some instances, well demonstrated, cost-effective means of reducing the burden of ill health due to social disadvantage are at hand. But interventions for systemic problems such as poverty generally require 'upstream' solutions (McMichael, 1999). Proximal actions, such as food supplements delivered directly to poor children, or screening and immunisation services targeted to high-needs groups, have to be embedded in a population-wide approach to be effective.

Consciously or not, Rothman and his colleagues (1998) appeared to be reflecting their own, North American milieu, in a time when neoliberalism predominated. A similar political climate applied elsewhere. In the UK, a long period of Conservative rule (1979-97) had entrenched the view that social problems were primarily a result of harmful personal behaviours, despite persistent evidence of the importance of context (Graham, 1987). It was at this level, the level of individuals and families, Margaret Thatcher and her contemporaries argued, that interventions were most likely to succeed. In New Zealand, a country with a strong collectivist tradition and high levels of social welfare, it was a Labour administration that was responsible in 1984 for radical government disinvestment and corporate deregulation. The mindset of the Labour reformers 
(Roger Douglas and colleagues), which assumed that public benefits were maximised by promoting private wealth, dominated all policy debates in New Zealand in health, education and welfare until the early 2000 s.

Debates between conservative and more liberal thinkers in health have deep roots. For example, in the late 19th century, arguments about the importance of the milieu versus the microbe involved not only Bernard and Pasteur (as mentioned above) but also the two most eminent contemporary figures of German medical science - Rudolf Virchow ${ }^{6}$ and Robert Koch. In his preface to Thomas Brock's book, Robert Koch: A Life in Medicine and Bacteriology, Strick writes:

More extreme liberals, such as ... Virchow, insisted that social reforms for those living in destitute, unclean, underfed, overworked conditions were the only real cure for epidemic diseases. Virchow and his supporters would always be highly suspicious of germs as any kind of true causative agents, recognizing that the easiest way for a conservative government to avoid expensive and democratizing social reforms was to blame epidemics entirely upon a germ from without, and so to avoid issues of poverty and inequality altogether and insist that all that was needed was quarantine and disinfection. (Strick, 1998)

This argument can be broadened beyond infectious diseases: poorer people smoke more, eat less healthily and have numerous other behaviours that increase their risk of many non-infectious diseases. Virchow's distrust of a 'germs only' explanation of disease has implications for the epidemiological skirmishes of the late 20th century. Since the papers by Rothman and his like-minded colleagues, the pendulum has swung some way 'upstream'. Many epidemiologists have pointed out that the microscopic view of disease causation, on its own, is inadequate (Blakely and Woodward, 2000; Mackenbach, 2009). There has been a growing interest in systems thinking, recognising that the health of populations is more than the sum of the individual components and increasing application of techniques such as systems dynamic modelling to investigate the emergence and spread of modern outbreaks (Galea et al., 2010).

The WHO Commission for the Social Determinants of Health (2008) has modernised the argument that social inequality is a root cause of ill health. Its work culminated in the 2011 Rio Political Declaration, endorsed subsequently by the World Health Assembly, committing national governments to improve public health by eradicating poverty and improving daily living conditions. Even so, in most countries, there are still substantial inequalities in health, and in some instances the gap between the most and the least advantaged groups in society has increased, suggesting the wider battle is being lost (OECD, 2011).

6 Virchow is reported to have opposed the revolutionary hygienic insights of Ignaz Semmelweiss. 


\section{Infectious Diseases}

McMichael also engaged in infectious diseases epidemiology (Weiss and McMichael, 2004) (Reprint H, Part 6, this volume). As his career started, some leading US figures were reported as pronouncing the demise of infectious diseases (though perhaps not US Surgeon General William Stewart, as has been widely reported) (Spellberg and Taylor-Blake, 2013). But in Philadelphia in 1976, an epidemic occurred that came to be called Legionnaires disease, raising concerns that infections could make a comeback. This was followed by initially mysterious but disturbing reports from Africa (later associated with Haiti and then among gay men, especially in the USA) of what was sometimes called slim disease, but is now known as HIV/AIDS. McMichael's contribution was not in these areas of new and emerging diseases, but rather in furthering our understanding of the implications of climate and other forms of global environmental change for familiar and re-emerging infectious diseases. His research drew attention to the role of social and economic factors in shaping the epidemiological distribution and persistence of 'old' infectious diseases such as malaria and schistosomiasis, and the importance of an integrated approach to ecological change, environmental change and infectious diseases. The association between environment, vector and host has been the domain of particular concern to the Special Programme for Research and Training in Tropical Diseases (TDR), and in the preparation of the Global Report for Research on Infectious Diseases of Poverty (TDR 2012). McMichael co-chaired a multidisciplinary group into Environment, Agriculture and Infectious Diseases of Poverty, published as a WHO Technical Report in 2013 (McMichael et al., 2013). Several chapters (24-27, this volume) focus on infectious diseases and their relationship to environmental change. Other chapters in this volume discuss different aspects of environmental change and non-infectious disease (Chapters 8, 28-29, 31).

\section{Conclusion}

McMichael's contributions are numerous and distinguished. The academic contributions mentioned above and amplified in this book demonstrate his innovation and leadership. This book, extensive as it is, is far from comprehensive. Many colleagues who could not write chapters for this book have contributed by reviewing them, others have sent photographs (see Figure 1.1) and tributes. Many attended the conference, held in late 2012, that marked Tony's formal retirement, including several from overseas. 


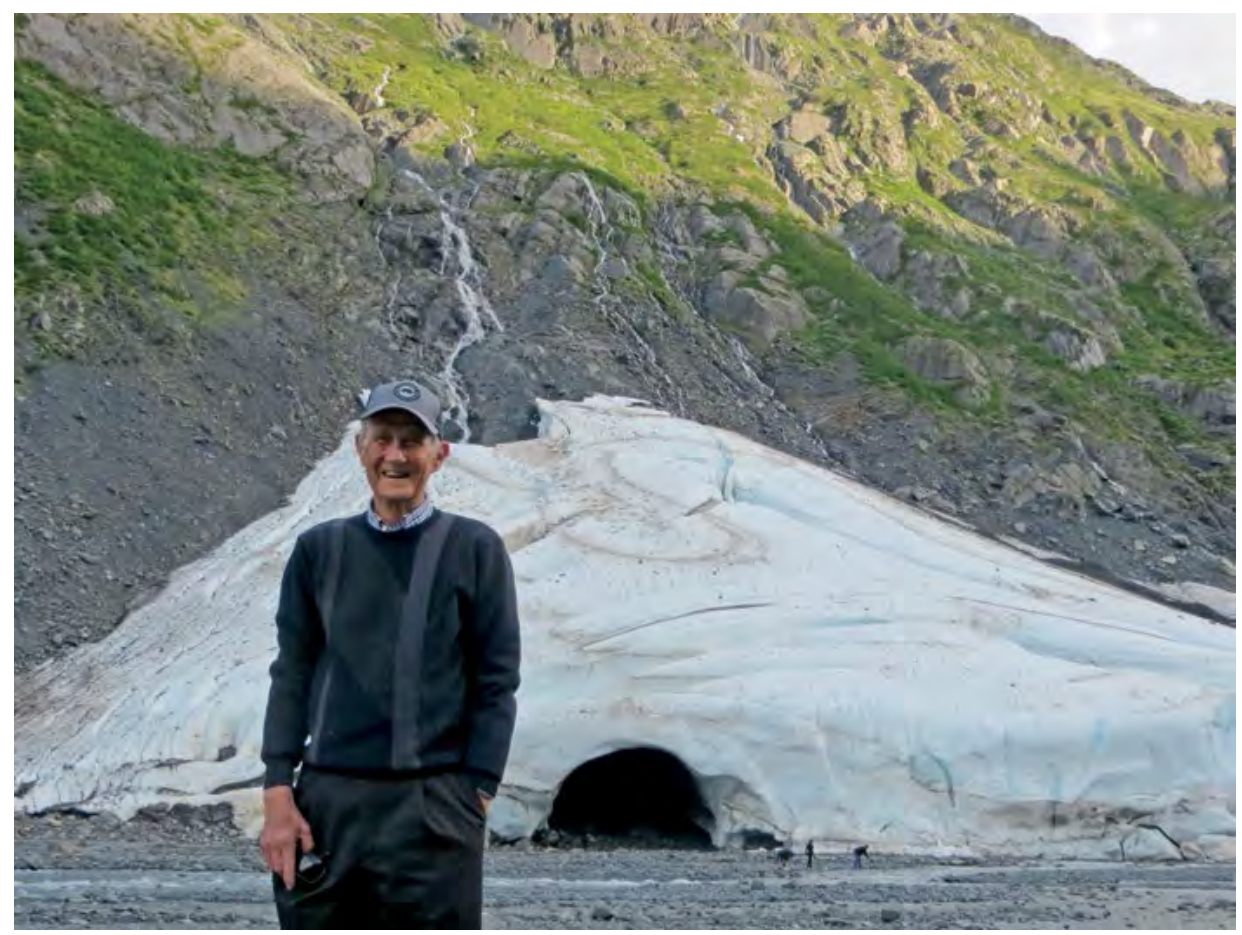

Figure 1.1 Tony McMichael in Anchorage, Alaska, where he spoke at the 20th International Epidemiological Association congress.

Source: Kristie Ebi.

McMichael nurtured and supported the career of many early-career researchers. His career demanded prodigious energy and remarkable attention to detail. He was blessed by the support of his wife, Associate Professor Judith Healy, two talented daughters and his musical skill and appreciation, especially of the piano. Several of his immediate family shared his musical and/or academic talents and interests, including his brother Philip (Chapter 16, this volume). Other forms of art also have a place in this book (Chapter 3, this volume).

And while McMichael consistently stressed the importance of quantitative work, he was open also to qualitative issues and recognised the importance of social science to public health (e.g. Chapters 16 and 20, this volume). His ability to focus on detail was combined with an ability to look at the big picture, and to encourage others to do the same. He also had considerable diplomatic skills, perhaps most evident in the chairing of scientific groups, including for the IARC, the National Health and Medical Research Council (NH\&MRC), the UK's Medical Research Council, WHO, the Millennium Ecosystem Assessment, the IPCC, the TDR and the Earth System Science Partnership. He nurtured many students and early-career researches. Several students whom Tony recently 
supervised or helped in other ways have contributed here (Chapters 4, 8, 17, 20, 23, 25, 26 and 32, this volume). Other authors in this book were students of Tony in the past (Chapters 7 and 12-14, this volume).

McMichael also made important contributions to non-government organisations, including The Australia Institute (Director 2002-10) ${ }^{7}$, The Climate Institute (Board member 2005-14) and the Frank Fenner Foundation (also until his passing in 2014). As well as his presidency of the ISEE, McMichael was president of the Public Health Association of Australia from 1988 to 1990. He also made substantial contributions to policy development, including for Doctors for the Environment Australia.

McMichael displayed persistent courage. Tony's testing interactions with tobacco companies over passive smoking are described in Chapter 12, this volume (see also Everingham and Woodward, 1991). The work in Port Pirie challenged the lead industry, and Tony also faced concerns in the community that there would be unemployment and economic hardship if controls on emissions caused the smelter to close. Later, his work challenged even more powerful commercial interests, those of the fossil fuel and meat industries (McMichael et al., 2007). He showed academic fortitude, repeatedly raising topics considered to be outside the disciplinary mainstream, such as ecology and population.

Trapped in time, it can be hard to discern the shift of the continually evolving milieu in which we are embedded. When we wrote the first draft of this chapter, a prolonged heatwave of unprecedented severity and extent had affected most of Australia. While younger people may be assuming there is nothing unusual in ever more extreme weather, the then Australian Prime Minister, Julia Gillard, linked this extended heatwave to climate change, ${ }^{8}$ an opportunity missed during the severe Australian east coast floods of 2011 and 2013.

It is not clear what lies ahead. For example, will the Australian Government join with others to call for emergency action to phase out fossil fuels rapidly? In any case, McMichael's heirs and successors face a plethora of challenges. Some (population growth, for instance) were visible in 1972; others, such as climate change, are only now taking full shape. There are opportunities to meet these challenges, such as new technologies to harness renewable energy sources, but many obstacles remain, including those of vested interest and denial. Other chapters in this volume describe the agenda for 21st-century epidemiology in more detail. We hope this book will introduce McMichael's work to a new audience, and that some of those readers will feel inspired to follow in his path.

7 He served on the research committee for The Australia Institute until his death.

8 www.theage.com.au/environment/weather/prepare-for-more-scorchers-gillard-warns-20130107-2ccve. html, accessed 10 April 2015. 


\section{References}

Ambrose, T.M., Al-Lozi, M. \& Scott, M.G. 2000. Bone lead concentrations assessed by in vivo X-ray fluorescence. Clinical Chemistry 46, 1171-8.

Blakely, T. \& Woodward, A. 2000. Ecological effects in multi-level studies. Journal of Epidemiology and Community Health 54, 367-74.

Boyden, S. 1972. The environment and human health. The Medical Journal of Australia 116, 1229-34.

Butler, C.D. 2008. Sustainable health for all by the year 2100? International Journal of Public Health 53, 223-4.

Callendar, G.S. 1957. On the amount of carbon dioxide in the atmosphere. Tellus 9, 421 .

Carson, R. 1962. Silent Spring. Houghton Mifflin, Boston, Massachusetts, USA.

Cicerone, R.J. 1988. Methane linked to warming. Nature 334, 198.

Commission for the Social Determinants of Health, 2008. Closing the Gap in a Generation. Health equity through action on the social determinants of health. World Health Organization, Geneva.

Dubos, R. 1980. The Wooing of Earth. Charles Scribner's Sons, New York, USA.

Duster, T. 2006. Lessons from history: why race and ethnicity have played a major role in biomedical research. The Journal of Law, Medicine \& Ethics 34, 487-96.

Editorial 1989. Health in the greenhouse. The Lancet 333, 819-20.

Ehrlich, P.R. 1968. The Population Bomb. Ballantyne, London, UK.

Ehrlich, P.R. \& Ehrlich, A.H. 2013. Can a collapse of global civilization be avoided? Proceedings of the Royal Society B: Biological Sciences 280. DOI: $10.1098 / \mathrm{rspb} .2012 .2845$.

Everingham, S. \& Woodward, S. 1991. Tobacco Litigation. The Case Against Passive Smoking AFCO $v$ TIA. Legal Books, Sydney, New South Wales, Australia.

Galea, S., Riddle, M. \& Kaplan, G. 2010. Causal thinking and complex system approaches in epidemiology. International Journal of Epidemiology 39, 97-106.

Goldstein, D.S. 2008. Computer models of stress, allostasis, and acute and chronic diseases. Annals of the New York Academy of Sciences 1148, 223-31. 
Graef, C., Hestnes, A.G., Svenning, M.M. \& Frenzel, P. 2011. The active methanotrophic community in a wetland from the High Arctic. Environmental Microbiology Reports 3, 466-72.

Graham, H. 1987. Women's smoking and family health. Social Science \& Medicine $25,47-56$.

Hetzel, B.S. \& McMichael, A.J. 1987. The LS Factor: Lifestyle and Health. Penguin, Melbourne, Victoria, Australia.

Hill, A.B. 1965. The environment and disease; association or causation? Proceedings of the Royal Society of Medicine 58, 295-300.

James, D.G. 1982-84. The Hunterian oration on Louis Pasteur's final judgement. Host reaction, soil or terrain. Transactions of the Medical Society of London 99-100, 131-47.

Lanphear, B.P., Hornung, R., Khoury, J., Yolton, K., Baghurst, P., Bellinger, D.C., et al. 2005. Low-level environmental lead exposure and children's intellectual function: an international pooled analysis. Environmental Health Perspectives 113, 894-9.

Lappé, F.M. \& Collins, J. 1971. Diet for a Small Planet. Institute for Food and Development Policy, San Francisco, California, USA.

Last, J.M. 1994. New pathways in an age of ecological and ethical concerns. International Journal of Epidemiology 23, 1-4.

Leaf, A. 1989. Potential health effects of global climatic and environmental changes. The New England Journal of Medicine 321, 1577-83.

Mackenbach, J. 2009. Politics is nothing but medicine at a larger scale: reflections on public health's biggest idea. Journal of Epidemiology and Community Health 63, 181-4.

McMichael, A. 1991. Global warming, ecological disruption and human health: the penny drops [editorial]. Medical Journal of Australia 154, 499-501.

McMichael, A.J. 1993a. Global environmental change and human population health: a conceptual and scientific challenge for epidemiology. International Journal of Epidemiology 22, 1-8.

McMichael, A.J. 1993b. Planetary Overload. Global Environmental Change and the Health of the Human Species. Cambridge University Press, Cambridge, UK.

McMichael, A.J. 1995. Contemplating a one child world. Falling grain stocks and rising population spell disaster and demand debate. BMJ 311, 1651-2. 
McMichael, A.J. 1998. The role of epidemiologists in eradicability of poverty. The Lancet 352, 1627.

McMichael, A.J. 1999. Prisoners of the proximate: Loosening the constraints on epidemiology in an age of change. American Journal of Epidemiology 149, 887-97.

McMichael, A.J. \& Hetzel, B.S. 1974. An epidemiological study of the mental health of Australian university students. International Journal of Epidemiology 3, 125-34.

McMichael, A.J. \& Hetzel, B.S. 1975. Mental health problems among university students, and their relationship to academic failure and withdrawal. The Medical Journal of Australia 1, 499-504.

McMichael, A.J. \& Potter, J.D. 1980. Reproduction, endogenous and exogenous sex hormones and colon cancer: a review and hypothesis. Journal of the National Cancer Institute 65, 1201-7.

McMichael, A.J., Andjelkovic, D.A. \& Tyroler, H.A. 1976. Cancer mortality among rubber workers: an epidemiologic study. Annals of the New York Academy of Sciences 271, 125-37.

McMichael, A.J., Haines, A., Slooff, R. \& Kovats, S. (eds) 1996. Climate Change and Human Health. World Health Organization, Geneva, Switzerland.

McMichael, A.J., Powles, J., Butler, C.D. \& Uauy, R. 2007. Food, livestock production, energy, climate change and health. The Lancet 370, 1253-63.

McMichael, A.J., Zhou, Z.-N., Blignaut, J., Bradshaw, C., Butler, C.D., Gillespie, S., et al. 2013. Research Priorities for the Environment, Agriculture and Infectious Diseases of Poverty. World Health Organization, Geneva, Switzerland.

Meadows, D., Meadows, D., Randers., J. \& Behrens III, W. 1972. The Limits to Growth. Universe Books, New York, USA.

OECD 2011. Divided We Stand. Why Inequality Keeps Rising. An Overview of Growing Income Inequalities in OECD Countries: Main Findings. OECD, Paris France. www.oecd.org/els/soc/dividedwestandwhyinequalitykeepsrising. htm, accessed 19 February 2015.

Peters, G.P., Andrew, R.M., Boden, T., Canadell, J.G., Ciais, P., Quéré, C.L., et al. 2012. The challenge to keep global warming below $2^{\circ} \mathrm{C}$. Nature Climate Change 3, 4-6.

Piel, G. \& Segerberg, O. Jr (eds) 1990. The World of René Dubos: A Collection from His Writings. Henry Holt and Company, New York, USA. 
Potter, J.D. \& McMichael, A.J. 1983. Large bowel cancer in women in relation to reproductive and hormonal factors: a case-control study. Journal of the National Cancer Institute 71, 703-9.

Rahmstorf, S., Foster, G. \& Cazenave, A. 2012. Comparing climate projections to observations up to 2011. Environmental Research Letters 7, 044035 (5 pp.).

Rose, G. 1992. The Strategy of Preventive Medicine. Oxford University Press, Oxford, UK, New York, USA.

Rothman, K.J., Adami, H.-O. \& Trichopoulos, D. 1998. Should the mission of epidemiology include the eradication of poverty? The Lancet 352, 810-4.

Sachs, J. 2012. The Price of Civilization. Vintage Books, London, UK.

Schellnhuber, H. 2010. Tragic triumph. Climatic Change 100, 229-38.

Sears, P.B. 1964. Ecology - a subversive subject. Bioscience 14, 11-3.

Shakhova, N., Semiletov, I., Salyuk, A., Yusupov, V., Kosmach, D. \& Gustafsso, Ö. 2010. Extensive methane venting to the atmosphere from sediments of the East Siberian Arctic shelf. Science 327, 1246-50.

Shepard, P. \& McKinley, D. 1969. The Subversive Science: Essays Towards an Ecology of Man. Houghton Miflin, Boston, Massachusetts, USA.

Shepherd, A., Ivins, E.R., Geruo, A., Barletta, V.R., Bentley, M.J., Bettadpur, S., et al. 2012. A reconciled estimate of ice-sheet mass balance. Science 338, 1183-9.

Sinding, T.S.W. 2000. The great population debates: how relevant are they for the 21st century? American Journal of Public Health 90, 1841-5.

Spellberg, B. \& Taylor-Blake, B. 2013. On the exoneration of Dr William H. Stewart: debunking an urban legend. Infectious Diseases of Poverty 2, 3. doi:10.1186/2049-9957-2-3 www.idpjournal.com/content/2/1/3, accessed 19 February 2015.

Strick, J. 1998. Preface. Robert Koch: A Life in Medicine and Bacteriology (Thomas $D$ Brock). Springer, Berlin, Germany. 202.114.65.51/fzjx/wsw/newindex/ wswfzjs/pdf/koch.pdf, accessed 1 July 2015.

Szreter, S. 1997. Economic growth, disruption, deprivation, disease and death: on the importance of the politics of public health. Population and Development Review 23, 693-728.

Taubes, G. 1995. Epidemiology faces its limits. Science 269, 164-9. 
Taylor, M.P., Camenzuli, D., Kristensen, L.J., Forbes, M. \& Zahran, S. 2013. Environmental lead exposure risks associated with children's outdoor playgrounds. Environmental Pollution 178, 447-54.

TDR, 2012. Global Report for Research on Infectious Diseases of Poverty. TDR, Geneva, Switzerland.

Trenberth, K.E. 2011. Attribution of climate variations and trends to human influences and natural variability. WIREs Climate Change 2, 925-30.

Tribe, D. 1994. Feeding and Greening the World. CAB International in association with the Crawford Fund for International Agricultural Research, Wallingford, UK.

Weiss, R.A. \& McMichael, A.J. 2004. Social and environmental risk factors in the emergence of infectious diseases. Nature Medicine 10, S70-6.

Werner, D. \& Sanders, D. 1997. Questioning the Solution: the Politics of Primary Health Care and Child Survival. HealthWrights, Palo Alto, California, USA.

Woodward, A. \& Kawachi, I. 2000. Why reduce health inequalities? Journal of Epidemiology and Community Health 54, 923-9.

World Cancer Research Fund Panel (Potter J.D. Chair) 1997. Food, Nutrition, and the Prevention of Cancer: A Global Perspective. American Institute for Cancer Research, Washington, DC, USA. 
This text is taken from Health of People, Places And Planet:

Reflections based on Tony McMichael's four decades of contribution to epidemiological understanding, edited by Colin D. Butler, Jane Dixon and Anthony G. Capon, published 2015 by ANU Press, The Australian National University, Canberra, Australia. 